\title{
Breakthrough in the assessment of cerebral perfusion and vascular permeability after brain trauma through the adoption of dynamic indocyanine green-enhanced near-infrared spectroscopy
}

\author{
Mario Ganau ${ }^{1}$, Mohammad Iqbal ${ }^{1}$, Gianfranco K. I. Ligarotti ${ }^{2}$, Nikolaos Syrmos ${ }^{3}$ \\ ${ }^{1}$ Department of Clinical Neurosciences, John Radcliffe Hospital, Oxford University, UK; ${ }^{2}$ Institute of Aerospace Medicine, Milan, Italy; ${ }^{3}$ Faculty of \\ Health Sciences, Aristotle University of Thessaloniki, Thessaloniki, Greece
}

Correspondence to: Mario Ganau, MD, PhD, FEBNS, FACS. Oxford University Hospitals NHS Foundation Trust, Oxford, UK.

Email: Mario.Ganau@alumni.harvard.edu.

Provenance and Peer Review: This article was commissioned by the editorial office, Quantitative Imaging in Medicine and Surgery. The article did not undergo external peer review.

Comment on: Forcione M, Yakoub KM, Chiarelli AM, Perpetuini D, Merla A, Sun R, Sawosz P, Belli A, Davies DJ. Dynamic contrast-enhanced nearinfrared spectroscopy using indocyanine green on moderate and severe traumatic brain injury: a prospective observational study. Quant Imaging Med Surg 2020;10:2085-97.

Submitted Jul 22, 2020. Accepted for publication Aug 01, 2020.

doi: 10.21037/qims-20-905

View this article at: http://dx.doi.org/10.21037/qims-20-905

The multifaceted pathophysiology of traumatic brain injury (TBI) varies across the hyper-acute, acute, subacute and chronic phases (1-3): differences obviously exist depending on the mechanisms and severity of the TBI, as well as the type of post-traumatic injuries (open versus closed TBI, concussive versus non-concussive, characterised by the presence of focal or diffuse intracranial injuries). TBI induces endothelial cell impairment of the bloodbrain barrier (BBB), but also mitochondrial dysfunction, disruption of cerebral autoregulation, cerebral blood flow velocity and cerebral vasoconstriction (4-8). Over the years, multimodality monitoring has been proposed to assess the pervasive changes unfolding after TBI $(9,10)$; the study from Forcione et al. (11) expands on this area of research by exploring the application of commercially available optical devices to perform contrast-enhanced near-infrared spectroscopy (NIRS) analysis in acute, adult patients sustaining moderate and severe TBI. One of the aims of their investigation is to detect differences between patients with TBI and those with extracranial trauma (nonTBI), and this would certainly be useful to answering some of the greatest clinical challenges in the management of polytraumas in general, and brain trauma care in particular (12).

Previous studies attempted to assess the cerebral perfusion and vascular permeability after brain trauma by monitoring the kinetics of a contrast dye, indocyanine green (ICG), with NIRS device (13-19). However, Forcione et al. (11) are the first group to provide experimental evidence supporting the belief that the assessment of the ICG kinetic by contrast-enhanced NIRS could effectively help clinicians choosing the most suitable treatment for each patient, based on their levels of cerebral perfusion and BBB integrity.

This pilot study explored the possibility of retrieving distinct elements from the optical signal from the ICG kinetic between TBI and non-TBI patients, which can then be linked to differences in cerebral perfusion and BBB integrity. Future clinical trials with bigger sample sizes could explore the parameters suggested herein as markers for assessment of TBI patients.

The authors have also the merit to describe well the current challenges and limitations in the acquisition and analysis of optical data with regards to trauma patients. 
These limits are discussed in depth, and their considerations could be relevant to the planning of future international clinical trials.

The clinical use of commercially available NIRS devices in hospital environments is still limited by a series of barriers: one of the biggest challenges is the training needed to provide clinical personnel with the practical skills to independently use point of care (PoC) diagnostics. With regards to NIRS, the lack of those competences will necessarily limit the possibilities to obtain data of sufficient quantity, and high quality, to monitor the ICG kinetic. However, these types of knowledge barriers go beyond the difficulties in acquiring reliable optical data, they also expose the critical importance of an effective organisation of trauma centres and their propensity toward continuous clinical and non-clinical improvement, which may well have repercussion in any other multicentre clinical study on TBI.

Another significant element exposed by this pilot study is the long time required for in vivo ICG spectral stabilization compared to in vitro studies. Based on the evidence acquired through their measurements, the authors also argue that the ICG spectral stabilization process may vary between patients. This is particularly relevant because in vitro studies showed a relatively quick spectral stabilization of the ICG, and multiple authors had previously suggested the ICG concentration could be translated into absolute values of physiological parameters in the assessment of conscious and unconscious TBI patients managed with maximum medical treatment or decompressive craniectomy (20-25). If the instability of ICG in vivo, as presumed according to this study, were to be confirmed by more in-depth analysis on larger sample sizes, the conclusions from Forcione et al. (11) may call into question the capacity to obtain absolute parameters of cerebral blood flow and BBB damage from optical analyses, where the ICG optical properties are considered stable.

In conclusion, the results of this pilot study represent a valuable add to the growing body of evidence on the adoption of new quantitative diagnostics (including PoC ones) meant to optimise the management of TBI patients (26-28). The take home message is sound and clear, as proposed by many neurotrauma research groups (29-30), it calls for engagement of multiple specialists, from neurosurgeons to neuroradiologists, from anaesthetists to intensivists, in adopting emerging methodologies, such as contrast-enhanced NIRS with ICG, for data collection, analysis, stratification and prognostication of TBI patients.

\section{Acknowledgments}

Funding: None.

\section{Footnote}

Conflicts of Interest: All authors have completed the ICMJE uniform disclosure form (available at http://dx.doi. org/10.21037/qims-20-905). MG serves as an unpaid editorial board member of Quantitative Imaging in Medicine and Surgery. The other authors have no conflicts of interest to declare.

Open Access Statement: This is an Open Access article distributed in accordance with the Creative Commons Attribution-NonCommercial-NoDerivs 4.0 International License (CC BY-NC-ND 4.0), which permits the noncommercial replication and distribution of the article with the strict proviso that no changes or edits are made and the original work is properly cited (including links to both the formal publication through the relevant DOI and the license). See: https://creativecommons.org/licenses/by-nc-nd/4.0/.

\section{References}

1. Cash A, Theus MH. Mechanisms of Blood-Brain Barrier Dysfunction in Traumatic Brain Injury. Int J Mol Sci 2020;21:3344.

2. Syrmos N, Ganau M, De Carlo A, Prisco L, Ganau L, Valadakis V, Grigoriou K, Iliadis C, Arvanitakis D. Dealing with the surgical and medical challenges of penetrating brain injuries. Case Rep Surg 2013;2013:209750.

3. Ganau L, Prisco L, Ganau M. High altitude induced bilateral non-traumatic subdural hematoma. Aviat Space Environ Med 2012;83:899-901.

4. Len TK, Neary JP, Asmundson GJ, Candow DG, Goodman DG, Bjornson B, Bhambhani YN. Serial monitoring of $\mathrm{CO} 2$ reactivity following sport concussion using hypocapnia and hypercapnia. Brain Inj 2013;27:346-53.

5. La Fountaine MF, Toda M, Testa AJ, Hill-Lombardi V. Autonomic Nervous System Responses to Concussion: Arterial Pulse Contour Analysis. Front Neurol 2016;7:13.

6. Yang J, Li Q, Wang Z, Han X, Lan X, Wan J, Wang W, Zhao X, Hou Z, Gao C, Carhuapoma JR, Mori S, Zhang J, Wang J. Multimodality MRI assessment of grey and white matter injury and blood-brain barrier disruption after intracerebral haemorrhage in mice. Sci Rep 2017;7:40358. 
7. Neary JP, Singh J, Bishop SA, Dech RT, Butz MJA, Len TK. An Evidence-Based Objective Study Protocol for Evaluating Cardiovascular and Cerebrovascular Indices Following Concussion: The Neary Protocol. Methods Protoc 2019;2:23.

8. Sharma A, Hind K, Hume P, Singh J, Neary JP. Neurovascular Coupling by Functional Near Infra-Red Spectroscopy and Sport-Related Concussion in Retired Rugby Players: The UK Rugby Health Project. Front Hum Neurosci 2020;14:42.

9. Ganau M, Prisco L. Comment on "neuromonitoring in traumatic brain injury". Minerva Anestesiol 2013;79:310-1.

10. Ganau L, Prisco L, Ligarotti GKI, Ambu R, Ganau M. Understanding the Pathological Basis of Neurological Diseases Through Diagnostic Platforms Based on Innovations in Biomedical Engineering: New Concepts and Theranostics Perspectives. Medicines (Basel) 2018;5:22.

11. Forcione M, Yakoub KM, Chiarelli AM, Perpetuini D, Merla A, Sun R, Sawosz P, Belli A, Davies DJ. Dynamic contrast-enhanced near-infrared spectroscopy using indocyanine green on moderate and severe traumatic brain injury: a prospective observational study. Quant Imaging Med Surg 2020;10:2085-97.

12. Ganau M, Syrmos N, Paris M, Ganau L, Ligarotti GKI, Moghaddamjou A, Chibbaro S, Soddu A, Ambu R, Prisco L. Current and Future Applications of Biomedical Engineering for Proteomic Profiling: Predictive Biomarkers in Neuro-Traumatology. Medicines (Basel) 2018;5:19.

13. Forcione M, Chiarelli AM, Davies DJ, Perpetuini D, Sawosz P, Merla A, Belli A. Cerebral perfusion and blood-brain barrier assessment in brain trauma using contrast-enhanced near-infrared spectroscopy with indocyanine green: A review. J Cereb Blood Flow Metab 2020;40:1586-98.

14. Weigl W, Milej D, Gerega A, Toczylowska B, Kacprzak M, Sawosz P, Botwicz M, Maniewski R, Mayzner-Zawadzka $\mathrm{E}$, Liebert A. Assessment of cerebral perfusion in posttraumatic brain injury patients with the use of ICG-bolus tracking method. NeuroImage 2014;85 Pt 1:555-65.

15. Liebert A, Milej D, Weigl W, Gerega A, Kacprzak M, Maniewski R. Fluorescence-based method for assessment of blood-brain barrier disruption. Conf Proc IEEE Eng Med Biol Soc 2013;2013:3040-2.

16. Milej D, Abdalmalak A, Desjardins L, Ahmed H, Lee TY, Diop M, St Lawrence K. Quantification of blood-brain barrier permeability by dynamic contrast-enhanced NIRS. Sci Rep 2017;7:1702.

17. Landsman ML, Kwant G, Mook GA, Zijlstra WG. Lightabsorbing properties, stability, and spectral stabilization of indocyanine green. J Appl Physiol 1976;40:575-83.

18. Wang MY, Luan P, Zhang J, Xiang YT, Niu H, Yuan Z. Concurrent mapping of brain activation from multiple subjects during social interaction by hyperscanning: a mini-review. Quant Imaging Med Surg 2018;8:819-37.

19. Mao Y, Zhuang Z, Chen Y, Zhang X, Shen Y, Lin G, Wu R. Imaging of glutamate in acute traumatic brain injury using chemical exchange saturation transfer. Quant Imaging Med Surg 2019;9:1652-63.

20. Tripp MR, Cohen GM, Gerasch DA, Fox IJ. Effect of protein and electrolyte on the spectral stabilization of concentrated solutions of indocyanine green. Proc Soc Exp Biol Med 1973;143:879-83.

21. Desmettre T, Devoisselle JM, Mordon S. Fluorescence properties and metabolic features of indocyanine green (ICG) as related to angiography. Surv Ophthalmol 2000;45:15-27.

22. Owen-Reece H, Elwell CE, Harkness W, Goldstone J, Delpy DT, Wyatt JS, Smith M. Use of near infrared spectroscopy to estimate cerebral blood flow in conscious and anaesthetized adult subjects. Br J Anaesth 1996;76:43-8

23. Deng W, Liu C, Parra C, Sims JR, Faiq MA, Sainulabdeen A, Song H, Chan KC. Quantitative imaging of the clearance systems in the eye and the brain. Quant Imaging Med Surg 2020;10:1-14.

24. Láng J, Ganau M, Prisco L, Bozsik K, Banczerowski P. Syndrome of trephined-underestimated and poorly understood complication after decompressive craniectomy. A trephined-szindróma - egy alulbecsült és kevéssé értett komplikáció dekompresszív craniectomia után. Ideggyogy Sz 2016;69:227-32.

25. Ganau M, Ligarotti GKI, Ganau L, Prisco L. Letter: Early Cranioplasty is Associated With Greater Neurological Improvement: A Systematic Review and Meta-Analysis. Neurosurgery 2018;83:E87-9.

26. Keller E, Nadler A, Niederer P, Yonekawa Y, Imhof HG. A new subdural probe for combined intracranial pressure (ICP) and cerebral blood flow (CBF) monitoring. Acta Neurochir (Wien) 2003;145:1111-5.

27. Arora R, Arora AJ. Justification of whole-body CT in polytrauma patients, can clinical examination help selecting patients? Quant Imaging Med Surg 2019;9:636-41. 
28. Ganau M, Lavinio A, Prisco L. Delirium and agitation in traumatic brain injury patients: an update on pathological hypotheses and treatment options. Minerva Anestesiol 2018;84:632-40.

29. van Dijck JTJM, Bartels RHMA, Lavrijsen JCM, Ribbers GM, Kompanje EJO, Peul WC, all focus group participants. The patient with severe traumatic brain

Cite this article as: Ganau M, Iqbal M, Ligarotti GKI, Syrmos $\mathrm{N}$. Breakthrough in the assessment of cerebral perfusion and vascular permeability after brain trauma through the adoption of dynamic indocyanine green-enhanced near-infrared spectroscopy. Quant Imaging Med Surg 2020;10(11):20812084. doi: 10.21037/qims-20-905 injury: clinical decision-making: the first $60 \mathrm{~min}$ and beyond. Curr Opin Crit Care 2019;25:622-9.

30. Hasan S, Chari A, Ganau M, Uff C. Defining New Research Questions and Protocols in the Field of Traumatic Brain Injury through Public Engagement: Preliminary Results and Review of the Literature. Emerg Med Int 2019;2019:9101235. 